\title{
Attachment to Significant Figures, Resilience, and Delinquency Among Adolescents in Orphanages in Jakarta
}

\author{
Winarini W. Mansoer ${ }^{\mathrm{a}}$, Raissa Dwifandra Putri ${ }^{\mathrm{b}}$, and Nesi Sulaiman ${ }^{\mathrm{c}}$
}

${ }^{a}$ Faculty of Psychology, University of Indonesia, Depok, Indonesia; ${ }^{b}$ Faculty of Psychology, University of Indonesia, Depok, Indonesia; ${ }^{c}$ Faculty of Psychology, University of Indonesia, Depok, Indonesia

*Corresponding Author:

Winarini W. Mansoer

Faculty of Psychology

University of Indonesia

Depok, Indonesia

Email address: winarini.d@ui.ac.id / winariniwd@gmail.com 


\title{
Attachment to Significant Figures, Resilience and Delinquency Among Adolescents in Orphanages in Jakarta
}

\begin{abstract}
Previous studies have found that delinquency is related to attachment to parents and peers as well as to resilience. Adolescents in orphanages were vulnerable to involvement in delinquency but they could be also more resilient. This study examined the relation between attachment to significant figures (father, mother, orphanage's caregivers, peers), resilience, and delinquency among adolescents in orphanages in Jakarta. Participants were 402 adolescents from 19 orphanages in Jakarta aged 11-19 years, consisting of 179 boys and 223 girls with middle and high school education. Results showed that participants had moderate attachment to significant figures and moderate resilience, and they were only engaged in mild delinquency. Resilience acted as a mediator in the relation between attachment to father and delinquency, while the attachment to caregivers was directly and negatively correlated with delinquency not mediated by resilience. Attachment to mother and peers did not correlate with resilience or with delinquency. It can be concluded that attachment to father and caregiver(s), as well as resilience had more influence in delinquency than attachment to mother and peers.
\end{abstract}

Keywords: significant figures, resilience, delinquency, adolescents, orphanage

\section{Introduction}

Delinquency is defined by a variety of forms of antisocial behavior consisting of illegal actions, both in the form of rules violations and criminal offenses, involving adolescents under the age of 18 (Shoemaker, 2010). Delinquency includes aggressive behavior, drug and alcohol use, and violence (Elliot \& Ageton, 1980; Reavy, Stein, Paiva, Quina, \& Rossi, 2012). In the United States, youth involvement in delinquency is quite high, such that delinquency has become a serious social problem for society (Salas-Wright, Vaughn, Hodge, \& Perron, 2012). In Malaysia there was an increase in delinquency by $50.24 \%$ in 2010 (23,642 people) compared to 2009 (Alpatanni, 2015).

In Indonesia, delinquency is also a serious problem. The National Police Headquarters in 2007 showed that 3,100 people involved in criminal cases were children under the age of 18 (BPS, 2010). Furthermore, the Indonesia National Child Protection Commission (KPAI) data showed that criminal acts involving children and adolescents were 35\% higher from January to October, 2009, compared to previous years (Indrijati, 2017). Data in Jakarta, shows the pattern of juvenile delinquency has led to criminal acts (Detiknews, 2013). Criminal acts committed by adolescents are things which disturb the safety of citizens. For example, chemicals used by students during street fights in Jakarta (Prihananto, 2017) as well as murders committed by adolescent fighting among/with friends in Malang (Surya \& Muiz, 2017).

Many studies have been conducted to investigate factors that correlate to delinquency. A study in the United States with 12.505 participants found that delinquency was influenced by parentchild reciprocity (attachment to child relationships with parents, parental involvement, and supervision) and poverty (Gault-Sherman, 2017). In Nigeria, delinquency was related to lack of parental supervision, poverty, and peer pressure (Ebuhi \& Omogbemi, 2011). In the United 
States some studies also found that family economic pressure and parenting were related to delinquency (Kwon \& Wickrama, 2014). In addition, it was found that in China and Canada delinquent playmates also influenced delinquency in the negative sense (Bao, Li, Zhang, \& Wang, 2015; Gallupe, 2015).

Jessor $(1968$; 1991) and Jessor and Jessor (1977) in the Problem Behavior Theory suggest that there are three main systems that influence behavior problems in adolescents, namely personality system (motivational structure, personal belief structure, and personal control structure), perceived environment (distant structure and close structure), and behavior system (problem behavior, healthy behavior, appropriate behavior). Within the systems, there are various factors that can be grouped into risk factors and protective factors for problem behavior among adolescents (Jessor, 1968; Jessor, 1991; Jessor \& Jessor, 1977). The combination of risk and protective factors can explain behavior problems such as delinquency. Protective factors in this theory can act as buffers from the effects of exposure to risk factors. Jessor and Turbin (2014) suggest the need for further studies to investigate protective factors and other risk factors in adolescent' behavior problems (Jessor \& Turbin, 2014).

One of the protective factors against delinquency is a positive relationship with parents (Shader, n.d). Positive relationship with parents could be built through secure attachment (Bowlby, 2006). Hirschi (1969) stated that attachment is an affective bond through with children internalizing conventional norm of society (Hoeve, Stams, van der Put, Dubas, van der Laan, \& Gerris, 2012). Based on Hirschi's theory, families with a high affective relationship will tend to minimize the risk of delinquency in adolescents. This is because, adolescents who have a high attachment relationship with their families will care more about parents' expectations of rules and norms that will trigger delinquency behavior. The quality of the attachment acts as an indirect parental control (Hoeve et al., 2012; Schluderman \& Schluderman, 1988).

A study explained that attachment to parents could buffer adolescents' involvement in delinquency. During adolescence, attachment should be combined with direct parental control such as supervision and discipline, in order to prevent delinquent behavior (Hoeve et al., 2012). Another study also explained that the warmth of relationships with parents and parental controls were related to adolescents' low involvement in externalizing behavior (Pinquart, 2017). Attachment to parents is felt subjectively by children as a result of parenting which is characterized by good communication, responsiveness, and without violence (Rettew, 2015; Barber, Stolz, \& Olsen, 2005).

Alegre, Benson's, and Pérez-Escoda's (2014) found that high maternal warmth was related to emotional security, and which in turn was associated with low emotional disturbances (i.e., internalizing problems) and behavioral disorders (i.e., externalizing problems). Conversely, the lack of warmth in parenting also caused norms violation behaviors (Kakihara, Tilton-Weaver, Kerr, \& Stattin, 2010). For children, parental warmth is a reward system that motivates them to engage in positive behavior (Padilla-Walker, Nielson, \& Day, 2010). 
In addition to parents, adolescents also build attachments to their peers or other community members (Lam, McHale, \& Crouter, 2014). For adolescents, building attachments to friends serves to assist them in understanding their self-concept, improving their self-identity, affecting positive emotional conditions and forming healthy social relationships (emotional and relational well-being) (Parker, Low, Walker, \& Gamm, 2005). Adolescents' attachment to their friends encourages self-disclosure in the form of expressing emotional feelings and psychological discussions about personal problems (Cicchetti \& Cohen, 2006; Sharabany. 1994). Adolescents who get emotional support from their friends showed higher self-confidence, emotional regulation ability and more positive social abilities (Rodri'guez, Perez-Brena, Updegraff, \& Umaña-Taylor, 2014).

In addition to attachment to significant figures, certain factors within individuals could also act as protectors for delinquency, such as resilience (Tweed, Bhatt, Dooley, Spindler, Douglas, \& Viljoen, 2011). Resilience is a form of an individual's ability to be able to utilize psychological, social, and physical resources (in the family environment etc.) and to maintain well-being while under pressure (Ungar, 2012). The development of adolescent resilience research currently includes five domains of individuals, which consist of self, family, peers, school, and community (Ungar, 2012; Gartland, Bond, Olsson, Buzwell, \& Sawyer, 2011). The existence of relationships with family members, peers, school staff, and community members who care for each other (caring) will each have a positive impact on adolescents (for example, getting high academic grades) and can reduce delinquency and violence (Tweed, 2011). Resilience could also be influenced by secure attachment with significant figures (parents, caregivers etc.) (Jenkins, 2016). Attachment to significant figures is shown among others by positive support for individuals. This is consistent with one study which states that to develop resilience, individuals need support from family members as well as other people (Atwool, 2006).

Orphanages are a unique context for adolescents, and which are significantly different from the traditional family context. There are various conditions that are typical of each orphanage that is related to the orphanage concept find in each respective country. In some countries, such as India, Cambodia, and Turkey, there are orphanages that provide home for orphans, where the children live entirely in that place (Naqshbandi, Sehgal, \& Ul Hassan, 2012; Ong, Yi, Tuot, Chhoun, Shibanuma, Yasuoka, \& Jimba, 2015; Simsek, 2008). There are also orphanages that have been replaced with foster home forms or living with host families such as in the United States (America's Adoption Agency, n.d).

The condition of orphanages in Indonesia has its own unique characteristics compared to orphanages in other countries. According to the Ministry of Social Affairs and UNICEF (2015) orphanages in Indonesia experienced a shift in function from being a care institution to an educational institution. In general, children who live in orphanages still have parents, but they have to live there due to their low socio-economic condition wherein their basic needs and education could not be met. The orphanage in Indonesia provides an opportunity for children to go home and meet their parents during certain periods (Personal interview with Mr. Sarsito, chairman of Asosiasi Pilar Kesejahteraan Indonesia, and Head of Yayasan Rumah Piatu Muslimin, April 4, 2017). Thus adolescents who live in orphanages could have relationships 
with their parents, even though they spend more time with the orphanages' caregivers and friends.

In relation to delinquency, Simsek, Erol, Oztop, and Munir (2007) found that adolescents in orphanages in Turkey were vulnerable to delinquency problems and the prevalence of externalizing behavior (including delinquency) was 21.4\% - 41.9\% (Simsek, Erol, Oztop, \& Ozcan, 2008). In addition, research in Bangladesh showed that $26.9 \%$ of teenagers in orphanages experience behavioral disorders, which consist of conduct disorder, oppositional disorder, hyperkinetic disorder, and other behavioral disorders (Rahman, Mullick, Pathan, Chowdhury, Shahidullah, Ahmed, Roy, Mazumder, \& Rahman, 2012).

In Indonesia, a study in orphanages in Padang showed that adolescents had behavioral problems, such as difficulties in adjusting to rules and friends, mocking their friends, swearing, fighting with friends, being unable to respect caregivers and friends, having difficulties socializing within the environment outside the orphanage. In addition, adolescents in the orphanage experience difficulties in establishing harmonious relationships with caregivers and friends, and prefer to be alone (Rahmah et al., 2014). Moreover, a study conducted in an orphanage in Kediri found that limited number of caregivers caused lack of attention to adolescents in orphanage so that they tended to show delinquent behaviors such as breaking school rules (e.g., truancy), harassing friends, and committing a criminal act (e.g., stealing cash in the mosque and in the shop) (Ningrum, 2012).

Adolescent delinquent behavior in orphanages was related to various problems faced by them in that the environment which were called as risk factors (Rahman et al., 2012; Rahmah et al., 2014; Hermenau, Hecker, Ruf, Schauer, Elbert, \& Schauer, 2011; Lassi, Mahmud, Syed, \& Janjua, 2011). The risk factors consisted of individual, family, peer, and environmental factors (Shader, n.d; Hawkins, Herrenkohl, Farrington, Brewer, Catalano, Harachi, \& Cothern, 2000).

Adolescents in orphanages are, on the one hand, vulnerable to involvement in delinquency (Simsek et al., 2008) but on the other hand, Pienaar, Swanepoel, van Rensburg, and Heunis (2011) found that adolescents in orphanages in Africa were generally more resilient. According to Pienaar et al (2011) there are four main components that can encourage/develop their resilience such as opportunities and external pressures, external supports, internal strengths, and interpersonal and problem solving skills. Thus, the relationship between resilience and delinquency in adolescents in orphanages (Pienaar et al., 2011) remains unclear.

Given that in orphanages in Indonesia, children are allowed to go home once in a while, they have the possibility to build an attachment to their parents as well as to caregivers and friends in the orphanage, so they have, overall, more significant figures (parents, caregivers, and friends). On the one hand, they have various problems in the orphanage context that could potentially cause them to become involved in delinquency, while on the other, they have an opportunity to receive support from many significant figures thus leading them to become more resilient. 
Mota and Matos (2015) found that resilience was a mediator between attachment to significant figures and well-being among adolescents in institutional care. Putri (2017) found that resilience correlated with delinquency among adolescents in orphanages in Jakarta, and resilience together with religiosity had a very small contribution on delinquency.

This study investigated: (1) adolescent attachment to significant figures, resilience, and delinquency and the relation among those variables, and; (2) resilience as a mediator between relations of attachment to significant figures and delinquency. This study could contribute to a better management of orphanages in relation to delinquency among adolescents under their care.

\section{Methods}

This is a correlational research. The variables in this study consisted of delinquency as the dependent variable and attachment to significant figures (father, mother, orphanage's caregiver, and friends as independent variables, and resilience as the mediator variable.

\section{Hypotheses}

It was hypothesized that:

- Attachment to father is correlated with delinquency;

- Attachment to mother is correlated with delinquency;

- Attachment to orphanage caregivers is correlated with delinquency;

- Attachment to friends is correlate $\mathrm{d}$ with delinquency;

- Resilience is correlated with delinquency;

- Attachment to father, mother, orphanage caregivers, and friends are correlated with delinquency with resiliency as a moderator.

\section{Participants}

Participants were recruited from 19 orphanages in Jakarta. The total participants were 402 adolescents, aged between $11-19$ years $(\mathrm{M}=14.88, \mathrm{SD}=1.94)$ which consisted of 179 male adolescents (44.5\%) and 223 female adolescents (55.5\%). Participants consisted of early adolescents $(40.8 \%)$, middle adolescents $(38.1 \%)$ and late adolescents $(21.1 \%)$. The reasons for living in the orphanage are low socio-economic background, and the loss of one or both parents. They live in an orphanage for an average period of 3.3 - 3.6 years, but may return every week, every month or during school holidays to the parents or relatives home.

\section{Instrument}

\section{Social Demographic Questionnaire}

To explain about gender, age, level of education, religion, status of parents, length of stay in the orphanage, reason for living in the orphanage, and frequency of going home.

\section{Children's Report of Parent Behavior Inventory (CRPBI-30)}

To measure the attachment to parents (mother and father) and orphanage's caregivers, we used the Children's Report of Parent Behavior Inventory (Schluderman \& Schluderman, 1988). This measuring has two subscales and 30 item questions that include respective (acceptance and 
psychological control) and firm control (discipline and lack of control). This measuring has been adapted into the Indonesian language e.g., "Mother, father, or orphanage's caregiver gives me attention and affection." The CRPBI-30 assessment scale is a score of 1-3. Score 1 describes "not similar," score 2 describes "somewhat similar," and score 3 describes "very similar." The highest score is 90, and the lowest score is 30 . This instrument has reliability Cronbach's Alpha $=0.857$ (Mother), reliability Cronbach's Alpha $=0.900$ (Father), reliability Cronbach's Alpha $=0.902$ (orphanage's caregiver), and validity $r>0.098$.

\section{Intimate Friendship Scale (IFS)}

Measurement of attachment to friends using the IFS (Sharabany, 1994). This measuring has eight subscales and 32 item questions consists of: frankness and spontaneity; sensitivity and knowing; attachment; exclusiveness; giving and sharing; imposition; common activity; trust and loyalty. This measuring instrument was adapted into Bahasa e.g., "I feel close to my friend." The IFS rating scale is $1-5$, one denoting "almost never" and five denoting "almost always." The highest is 160 , and the lower score is 32 . This instrument has reliability with Cronbach's Alpha $=0.929$ and validity $r>0.098$.

\section{Child and Youth Resilience Measure 28 (CYRM-28)}

Resilience measurement using Child and Youth Resilience Measures - 28 (Liebenberg, Ungar, \& Van de Vijver, 2011). This measuring has three subscales, and 28 initial items consisting of individual factor subscales (personal abilities, peer support, and social abilities), family/caregivers (physical care and psychological care), and contextual factors (religious, educational, and cultural). This instrument was adapted into Indonesian language, and the researcher translated each item that used "caregiver" into "parent" and "orphanage's caregiver," so that total number of items became 33 in total. Based on the validity test, the researchers used 31 items. Item example: (1) I can work with people around me (personal abilities); (2) I feel supported by my friends (peer support); (3) I participate in my religious group activities (social skills). The assessment scales of CYRM range from 1 to $5.1=$ very inappropriate and $5=$ very appropriate. The highest score is 155 and the lowest score is 31, with reliability Cronbach's Alpha $=0.908$, and validity $r>0.098$.

\section{Self-Report Delinquency Scale (SRDS)}

Delinquency in this study was measured using a SRDS has 44 items (Elliot \& Ageton. 1980; Wilson, 2013). The subscales of the SRDS consist of theft, crimes against persons, crimes against property, offense status, illegal service crimes, and drug use. Delinquency assessment subscale consists of $1=$ never, $2=1-2$ times a month, $3=$ once in 2-3 months, $4=$ once a month, $5=$ once in 2-3 weeks, $6=$ once in the week, $7=2-3$ times a week, $8=$ once a day, $9=2-3$ times a day. This instrument was adapted into Indonesian language. We translated this instrument to be adjusted to an orphanage context and added three more items, so that total number of items became 47. Based on the validity test, the researchers used 33 items. The highest score is 297, and the lowest score is 33. E.g., "I hit one of the caregivers in the home.'This instrument has reliability with a Cronbach's Alpha $=0.817$, validity $r>0.098$. 


\section{Procedure}

Before collecting data, researchers conducted interviews with administrators and several adolescents in orphanages and observed nursing homes and nursing homes. The research was carried out in the hall in each orphanage. Researchers explained the purpose of the study and asked the willingness of adolescents to become participants through informed consent. Data collection took 30-40 minutes. During the data collection, the researchers guided the participants in filling out the questionnaire. All ethical procedures in this study were fulfilled, which included explanations of research objectives, voluntary participation of participants and data confidentiality. At the end, researchers gave souvenirs as a token of gratitude to the participants.

\section{Data analysis}

Data was analyzed using correlation analysis to ascertain attachment to significant figures (mothers, fathers, orphanage's caregivers, and friends), resilience, and delinquency. Further analysis used the effects model to see the quality of attachment to significant figures in predicting adolescent delinquency in an orphanage. These model effects also examined the role of resilience as a mediator of these relations.

\section{Results}

\section{Description of Orphanages}

There were two types of orphanages- denominational/religious- based and non-denominational orphanages. The physical condition of buildings in 19 orphanages in Jakarta is classified as habitable (clean, there is sufficient lighting and large). Every child who lives in an orphanage received basic needs, such as food, clothing, caring, and education. Each bedroom consists of 5-10 children with one caregiver. The caregivers act as a person to whom children could share their feelings and experiences. They also help children to do their homework and other school assignments, and monitor as well as control children's behavior.

At each orphanage there are also various routine activities that are carried out together to improve the sense of brotherhood and camaraderie in the orphanage. Religious activities are carried out in all types of orphanages, e.g., for Moslem children to pray and to break fasting together during Ramadan; for Christian and Catholic children to have Sunday school activities and services. Each orphanage also provides talent development activities for each child such as sewing, farming, and entrepreneurship. The orphanages also provide additional help for children with learning difficulties. Once in a year, there is also a recreational activity for caregivers, and children in the orphanage.

Every child who lives in the institution is also taught to be responsible and disciplined through the orphanage rules. For example, getting out of bed on time and then cleaning up together, going home from school must be on time, playing and studying in a certain time, and having dinner together. Every child must accept the consequence if they break the rules e.g., going out without permission, not coming home on time from school or not washing the dishes. The 
alumni of the orphanage would come back once in a while to help with taking care of, or to guide their younger siblings in the orphanage.

\section{Descriptive analysis}

Table 1 showed that adolescents in orphanages in Jakarta had moderate attachment to significant figures and resilience, and they were only involved in mild delinquency. Table 1 showed that attachment to orphanage's caregivers was negatively correlated with delinquency $(\mathrm{r}=-0.14 ; \mathrm{p}<0.05)$, i.e., the higher the attachment to the orphanage's caregivers, the lower the involvement in delinquency. Attachment to father, mother, and friends was not correlated with delinquency. Resilience was negatively correlated with delinquency $(r=-0.17 ; p<0.05)$, which means the higher the resilience, the lower the involvement in delinquency. Only attachment to father was positively correlated with resilience $(r=0.15 ; p<0.05)$.

Table I. Correlation of Attachment to Significant Figures, Resilience, and Delinquency at the Orphanage in Jakarta

\begin{tabular}{lllllll}
\hline Variable & $(\mathbf{1})$ & $\mathbf{( 2 )}$ & $\mathbf{( 3 )}$ & $\mathbf{( 4 )}$ & $\mathbf{( 5 )}$ & $\mathbf{( 6 )}$ \\
\hline Attachment to mother (1) & - & & & & & \\
Attachment to father (2) & $0.62^{* *}$ & - & & & & \\
Attachment to orphanage's caregiver(3) & $0.33^{* *}$ & $0.39^{* *}$ & - & & & \\
Attachment to friends (4) & $0.16^{* *}$ & $0.15^{* *}$ & $0.19^{* *}$ & - & & \\
Resilience (5) & 0.07 & $0.15^{* *}$ & 0.09 & -0.03 & - & \\
Delinquency(6) & 0.01 & -0.06 & $-0.14^{*}$ & 0.04 & $-0.17^{*}$ & - \\
Mean & & & $*$ & & & \\
SD & 71.03 & 68.82 & 63.78 & 113.50 & 118.00 & 41.28 \\
$\mathrm{~N}$ & 8.11 & 8.97 & 8.56 & 20.74 & 18.32 & 11.85 \\
& 370 & 316 & 399 & 402 & 402 & 402 \\
\hline
\end{tabular}

Based on the correlation test, the variables which have a significant correlation were tested by the mediator model in the subsequent analysis. These variables consist of attachments to fathers and caregivers as independent variables, resilience as mediators, and delinquency as dependent variables.

The results showed that resilience acted as a mediator for relations between attachment to father and delinquency $(\beta=-0.02, \mathrm{p}<0.05)$. Attachment with father did not directly correlate with delinquency $(\beta=-0.05, \mathrm{p}>0.05)$ (Table 2$)$.

Table II. Effects of Resilience as a Mediator on Attachment to Fathers and Delinquency

\begin{tabular}{lllll}
\hline & B & SE & CI & p \\
\hline Significant Figure (Father)-Delinquency & -0.05 & 0.68 & $-0.18-0.09$ & $>0.05$ \\
Significant Figure (Father)-Resilience & 0.31 & 0.12 & $0.09-0.54$ & $<0.05$ \\
Resilience-Delinquency & -0.07 & 0.03 & $-0.14-(-0.01)$ & $<0.05$ \\
Significant Figure (Father-Resilience-Delinquency & -0.02 & 0.01 & $-0.06-(-0.01)$ & $<0.05$ \\
\hline
\end{tabular}




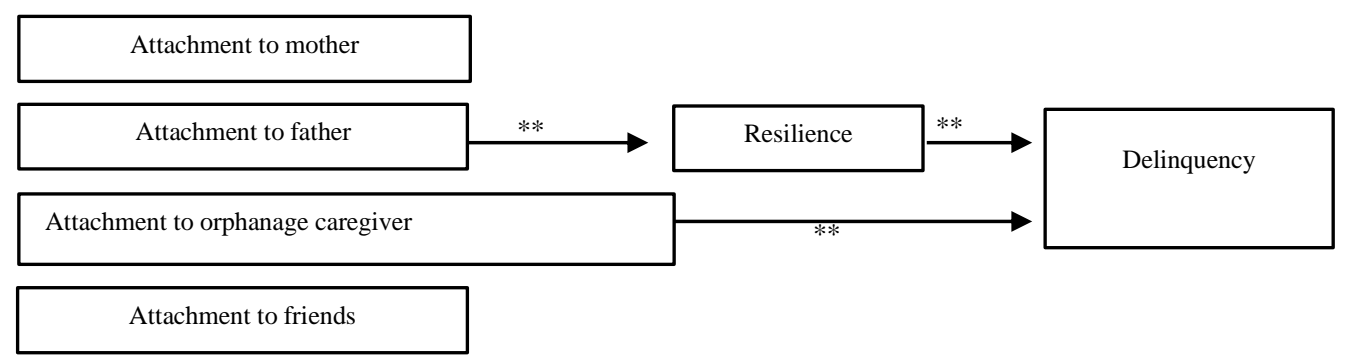

Fig.1. Attachment to Fathers and Orphanage's Caregivers, Resilience, and Delinquency

\section{Discussion and Conclusion}

In this study, adolescents in orphanages in Jakarta had moderate attachment to significant figures. As stated by Kassamali and Rattani (2014), attachment could be established if children have the opportunity to interact positively with significant figures. This is possible because even though they live in an orphanage they still have the opportunity to go home. However, adolescents in orphanages only have the opportunity to interact with their parents on a limited basis, while in orphanages, they also could not interact optimally with caregivers because the caregivers had to be responsible for a number of children.

In contrast to the Pineaar et al's (2011) study, participants only had moderate resilience. Based on the views of Ungar, Brown, Liebenberg, Cheung and Levine (2008) adolescents in this study (even though living in an orphanage) could achieve moderate resilience because they had the opportunity to get food, education, health facilities, support from significant figures, opportunities for self-development, programs for adherence to traditional and religious values (informal interviews and observations with caregivers and participants). However, they only get moderate support from a limited number of care givers and limited interaction with parents (Ungar et al., 2008).

Simsek et al., (2008) found that adolescents in orphanages in Turkey were more likely to be delinquent, however, this study found that adolescents in orphanages in Jakarta were only involved in mild delinquency. According to Jessor and Jessor (1977) and Jessor and Turbin (2014) delinquency is influenced by a combination of risk and protective factors such as personality system, role models, vulnerabilities, opportunities, risky behavior, controls, support, and protective behavior. In addition, Shader (n.d.) stated that protective and risks factors for delinquency in adolescents, namely: (1) individuals (innate factors, psychology, behavior and mental characteristics); (2) social factors (family, friends), and; (3) community factors (school policy, neighborhood). Adolescents in this study might have some protective factors, individually was moderate resilience, and environmentally, were programs and rules at the orphanage that were clear and structured with good supervision (observations and informal interviews with caregivers and participants) (Shader, n.d).

Only attachment with caregivers was directly and negatively correlated with delinquency. In line with Jessor and Turbin (2014) and Shader (n.d.), caregivers seem to play a role as protective factors (role models, controllers, supporters, and protectors). In adolescence, attachment by 
itself is insufficient to prevent delinquency i.e., it should be combined with direct parental control (Hoeve, 2012). Adolescents in orphanages in Jakarta were only involved in mild delinquency- this may well be related to the direct supervision and discipline received from caregivers.

Attachment to father and/or mother didn't have significant and direct correlation with delinquency. However, attachment to father was related to delinquency with the mediation of resilience. In line with Hoeve (2012), attachment and parental control attachment including supervision, rules setting, and strictness had more impact on the child's behavior than childparent attachment relationships alone. In this study, the existence of supervision, rules setting, and strictness toward adolescents who were more readily obtained from caregivers in an orphanage.

This study also found that only attachment to fathers correlated significantly with resilience. In line with the research of Zhang, Zhao, Jud, and Ma (2015) which noted that resilient individuals have been proven to share typical masculine personality. Father involvement encompasses characteristics such as being accepting and emotionally warm, and this being a significant predictor of children's capacity for empathy and social skills, better peer relationships, and overall behavioral and psychological adjustment. In this manner, fathers acted as mentors for children to achieve their (positive) social abilities. Resilience is one such social ability.

This study found a significant correlation between resilience and delinquency. This is in line with Ningrum (2012), which noted that resilience possessed by adolescents in orphanages allows them to engage in coping mechanisms to reduce involvement in delinquent behavior. Other studies also show that activities in orphanages develop adolescent skills that can prevent them from involvement in delinquency since it can encourage their self-efficacy (Mazaya \& Supradewi, 2011), positive self-efficacy and which in turn could enhance resilience (Sagone \& Caroli, 2016). This is in line with Jessor and Turbin (2014), namely that resilience is a crucial element in the everyday lives of adolescents.

Alpatanni (2008), found that adolescents in orphanages in Malaysia had a high level of delinquency. This is because most of the orphanage adolescents experience rejection and violence in the family. Unlike orphanages in Jakarta, the reason adolescents live in orphanages is primarily because of low socio-economic conditions. Hence, the risk factors of the behavior of adolescents in orphanages in Jakarta were different.

The difference in results from previous studies may be because the adolescents' opportunities to visit their parents while living in an orphanage meant their attachment to parents could still be maintained. At the same time, the characteristics- as well as the programs and management of the orphanages in Jakarta- may contribute to adolescents' moderate resilience and engagement in mild delinquent behaviors.

This study has several limitations, Firstly, measurements using self-reporting might be influenced by social desirability. Hence, in future research, measurements should include social 
desirability items. Secondly, the use of different measuring devices for attachment to parents/caregivers and friends, may cause different results. A future study could use the same measuring instruments, such as Inventory of Parents and Peer Attachment Revised (Armsden \& Greenberg, 1987). Finally, some values maybe missing as caused by translated instruments. Mixed method approaches could gather more in-depth information about adolescents' lives in orphanages, thereby allowing us to understand more the reasons behind the relations among variables.

Future research should be conducted in other cities and/or regions of Indonesia to look at the characteristics of orphanages that may serve as protective but also risk factors for delinquency among adolescents in orphanages.

\section{References}

Alegre, A., Benson, M. J., \& Pérez-Escoda, N. (2014). Maternal warmth and early adolescents' internalizing symptoms and externalizing behavior. Mediation Via Emotional Insecurity, 34, 712-735.

Alpatanni, P. (2015). Juvenile Delinquency in Malaysia. Malaysia: Open University Malaysia.

America's Adoption Agency. (n.d). Do orphanages still exist in America?. United States of America, USA: American Adoption.

Armsden, G., \& Greenberg, M. T. (1987). The inventory of parent and peer attachment: Individual differences and their relationship to psychological well-being in adolescence. Journal of Youth and Adolescence, 16, 427-454.

Atwool, N. (2006). Attachment and resilience: Implications for children in care. Child Care in Practice, 12, 315330.

Badan Pusat Statistik (2010). Profil Kriminalitas Remaja 2010. Jakarta: Badan Pusat Statistik

Bao, Z., Li, D., Zhang, W., \& Wang, Y. (2015). School climate and delinquency among Chinese adolescents: Analyses of effortful control as a moderator and deviant peer affiliation as a mediator. Journal of Abnormal Child Psychology. 43, 81-93.

Barber, B. K., Stolz, H. E., \& Olsen, J. A. (2005). Parental support, psychological control, and behavioral control: Assessing relevance across time, culture, and method. Monographs of the Society for Research in Child Development, 70, i-137.

Atwool, N. (2006). Attachment and resilience: Implications for children in care. Child Care in Practice, 12, 315330 .

Cicchetti, D., \& Cohen, D. J. (2006). Developmental psychopathology, Volume 3, Risk, disorder, and adaptation ( $2^{\text {nd }}$ ed.). United States, US: John Wiley \& Sons, Inc.

Detiknews.com. (2013). DPRD DKI: Kenakalan remaja sudah menjurus ketingkat kriminal. Retrieved from: https://news.detik.com/berita/d-2380867/-dprd-dki-kenakalan-remaja-jakarta-sudah-menjurus-ke-tingkatkriminal

Ebuhi, O. M., \& Omogbemi, K. B. (2011). Juvenile delinquency among students of an approved sheltered girls' school in Lagos, Nigeria. Nigerian Quarterly Journal of Hospital Medicine, 21, 50-58.

Elliot, D. \& Ageton, S. S. (1980). In Wilson M. (2013). Maltreatment and Youth Delinquency: The Relationship between Physical Neglect and Delinquent Behavior in Young Males (Master thesis). Massey University, New Zealand.

Gallupe, O. (2015). The influence of popular and delinquent adolescents on school delinquency: Specifying the key delinquent models. Journal of Crime and Justice, 40, 101-118.

Gartland, D., Bond, L., Olsson, C. A., Buzwell, S., \& Sawyer, S. M. (2011). Development of a multi-dimensional measure of resilience in adolescents: The adolescent resilience questionnaire. BMC Medical Research Methodology, 11, 134.

Gault-Sherman, M. (2017). It's a two-way street: The bidirectional relationship between parenting and delinquency. Journal of Youth and Adolescence, 41, 121-145. 
Hawkins, J. D., Herrenkohl, T. I., Farrington, D. P., Brewer, D., Catalano, R. F., Harachi, T. W., \& Cothern, L. (2000). Predictors of youth violence. Juvenile Justice Bulletin, 4, 1-11.

Hermenau, K., Hecker, T., Ruf, M., Schauer, E., Elbert, T., \& Schauer, M. (2011). Childhood adversity, mental ill-health and aggressive behavior in an African orphanage: Changes in response to trauma-focused therapy and the implementation of a new instructional system. Child and Adolescent Psychiatry and Mental Health, 5, 2-9.

Hirschi, T. (1969). In Hoeve, M., Stams, G. J. J. M., van der Put, C. E., Dubas, J. S., van der Laan, P. H., \& Gerris, J. R. M. (2012). A meta-analysis of attachment to parents and delinquency. Journal of Abnormal Child Psychology, 40, 771-785.

Hoeve, M., Stams, G. J. J. M., van der Put, C. E., Dubas, J. S., van der Laan, P. H., \& Gerris, J. R. M. (2012). A meta-analysis of attachment to parents and delinquency. Journal of Abnormal Child Psychology, 40, 771785 .

Indrijati, H. (2017). Juvenile delinquency of senior high school students in Surabaya, Indonesia. International Journal of Social, Behavioral, Educational, Economic, Business and Industrial Engineering, 11, 184-188.

Jenkins, J. K. (2016). The relationship between the resilience, attachment and emotional coping styles (Thesis). Norfolk, VA: Old Dominion University.

Jessor, R. (1991). Risk behavior in adolescence: A psychosocial framework for understanding and action. Journal of Adolescent Health, 12, 597-605.

Jessor, R., \& Jessor, S. L. (1977). Problem behavior and psychosocial development: A longitudinal study of youth. New York, NY: Academic Press.

Jessor, R. (2014). Problem Behavior Theory: A half-century of research on adolescent behavior and development. In J. Brooks-Gunn, R. M. Lerner, A. C. Petersen, \& R. K. Silbereisen (Eds.), The developmental science of adolescence: History through autobiography. New York: Psychology Press

Jessor, R., \& Turbin, M. S. (2014). Parsing protection and risk for problem behavior versus pro-social behavior among US and Chinese adolescents. Journal of Youth and Adolescence, 43, 1037-1051.

Kakihara, F., Tilton-Weaver, L., Kerr, M., \& Stattin, H. (2010). The relationship of parental control to youth adjustment: Do youths' feelings about their parents play a role?. Journal of Youth and Adolescence, 39, 1442-1456.

Kassamali, N., \& Rattani, S. A. (2014). Factors that affect attachment between the employed mother and the child, infancy to two years. Procedia - Social and Behavioral Sciences, 159, 6-15.

Kementerian Sosial Republik Indonesia \& UNICEF. (2015). Penilaian cepat program kesejahteraan sosial anak (PKSA). Jakarta: Kementerian Sosial Republik Indonesia

Kwon, J. A., \& Wickrama, K. A. (2014). Linking family economic pressure and supportive parenting to adolescent health behaviors: Two developmental pathways leading to health promoting and health risk behaviors. Journal of Youth and Adolescence, 43, 1176-1190.

Lam, C. B., McHale, S. M., \& Crouter, A. C. (2014). Time with peers from middle childhood to late adolescence: Developmental course and adjustment correlates. Child Development, 85, 1677-1693.

Lassi, Z. S., Mahmud, S., Syed, E. U., \& Janjua, N. Z. (2011). Behavioral problems among children living in orphanage facilities of Karachi, Pakistan: Comparison of children in an SOS village with those in conventional orphanages. Social Psychiatry and Psychiatric Epidemiology, 46, 787-796.

Liebenberg, L., Ungar, M., \& Van de Vijver, F. (2011). Validation of the child and youth resilience measure-28 (CRYM-28) among Canadian Youth. Research on Social Work Practice, 22, 219-226.

Mazaya, K. N., \& Supradewi, R. (2011). Konsep diri dan kebermaknaan hidup pada remaja di Panti Asuhan. Proyeksi, 6, 103-112.

Mota, C. P., \& Matos, P. M (2014). Adolescents in institutional care: Significant adults, resilience, and well-being. Child Youth Care Forum, 44, 209-224.

Naqshbandi, M. M., Sehgal, R., \& Ul Hassan, R. (2012). Orphans in orphanages of Kashmir and their Psychological problems. International NGO Journal, 7, 55-63.

Ningrum, N. A. (2012). Hubungan antara coping strategy dengan kenakalan pada remaja awal. Jurnal Psikologi, 7, 481-489. 
Ong, K. I. C., Yi, S., Tuot, S., Chhoun, P., Shibanuma, A., Yasuoka, J., \& Jimba, M. (2015). What are the factors associated with depressive symptoms among orphans and vulnerable children in Cambodia?. BMC Psychiatry, 15, 178.

Padilla-Walker, L. M., Nielson, M. G., \& Day, R. D. (2016). The role of parental warmth and hostility on adolescents' prosocial behavior toward multiple targets. Journal of Family Psychology, 30, 331.

Parker, J. G., Low, C. M., Walker, A. R., \& Gamm, B. K. (2005). Friendship jealousy in young adolescents: Individual differences and links to sex, self-esteem, aggression, and social adjustment. Developmental Psychology, 41, 235-250.

Pienaar, A., Swanepoel, Z., van Rensburg, H., Heunis, C. (2011). A qualitative exploration of resilience in preadolescent AIDS orphans living in a residential care facility. Journal of Social Aspects of HIV/AIDS, 8, 128-137.

Pinquart, M. (2017). Associations of parenting dimensions and styles with externalizing problems of children and adolescents: An updated meta-analysis. Developmental Psychology, 53, 873-932.

Prihananto, P.E. (2013). Kenakalan remaja makin mencemaskan. Retrieved from https://megapolitan.kompas.com/read/2013/10/08/0920254/Kenakalan.Remaja.Makin.Mencemaskan

Putri, R. D. (2017). Kontribusi religiusitas dan resiliensi terhadap perilaku delinkuen remaja di panti asuhan di Jakarta (The contibution of religiosity and resilience to delinquency among adolescents at orphanage in Jakarta) (Unpublished Master thesis). Universitas Indonesia, Depok.

Rahmah, S. Nurfahanah, N., Asmidir, A. (2014). Masalah-Masalah yang Dialami Anak Panti Asuhan dalam Penyesuaian Diri dengan Lingkungan. Konselor, 3, 107-112.

Rahman, W., Mullick, M. S. I., Pathan, M. A. S., Chowdhury, N. F., Shahidullah, M., Ahmed, H., Roy, S., Mazumder, A. H., \& Rahman, F. (2012). Prevalence of behavioral and emotional disorders among the orphans and factors associated with these disorders. Bangabandhu Sheikh Mujib Medical University Journal, 5, 29-34.

Reavy, R., Stein, L. A. R., Paiva, A., Quina, K., \& Rossi, J. S. (2012). Validation of the delinquent activities scale for incarcerated adolescents. Addictive Behaviors, 37, 875-879.

Rettew, D. (2015). Parental warmth: Simple, powerful, and often challenging. Retrieved from https://www.psychologytoday.com/intl/blog/abcs-child-psychiatry/201504/parental-warmth-simplepowerful-and-often-challenging?destination=node/1073621

Rodr1'guez, S. A., Perez-Brena, N. J., Updegraff, K. A., \& Uman a-Taylor, A. J. (2014). Emotional closeness in Mexican-origin adolescents' relationships with mothers, fathers, and same-sex friends. Journal of Youth and Adolescence, 43, 1953-1968.

Sagone, E., \& Caroli, M. E. D. (2016). Yes... I can: Psychological, resilience, and self-efficacy in adolescents. International Journal of Developmental and Educational Psychology, 1, 141-148.

Salas-Wright, C. P., Vaughn, M. G., Hodge, D. R., \& Perron, B. E. (2012). Religiosity profiles of American youth in relation to substance use, violence, and delinquency. Journal of Youth and Adolescence, 41, 1560-1575.

Schluderman, E., \& Schluderman, E. (1988). Replicability of factors in the children's report of parent behavior (CRPBI). Journal of Psychology, 96, 15-23.

Shader, M. (n.d). Risk Factor an delinquency: An overview. United States, US: Department of Justice.

Sharabany, R. (1994). Intimate friendship scale: Conceptual underpinnings, psychometric properties and construct validity. Journal of Social and Personal Relationships, 11, 449-469.

Shoemaker, D. J. (2010). Theories of delinquency an examination of explanations of delinquent behavior ( $\left.6^{\text {th }} \mathrm{ed}.\right)$. United States of America, USA: Oxford University Press.

Simsek, Z. Erol, N., Öztop, D., \& Munir, K. (2007). Prevalence and predictors of emotional and behavioral problems reported by teachers among institutionally reared children and adolescents in Turkish orphanages compared with community controls. Child and Youth Services Review, 29, 883-899.

Simsek, Z., Erol, N., Oztop, D., \& Ozcan, O. O. (2008). Epidemiology of emotional and behavioral problems in children and adolescents reared in orphanages: A national comparative study. Turkish Journal of Psychiatry, 19, 235-246.

Surya \& Muiz, A.A. (2017). Fakta-fakta siswi SMA bunuh teman sendiri, pengakuan saksi bikin merinding. Retrieved from https://www.tribunnews.com/regional/2017/12/30/fakta-fakta-siswi-sma-bunuh-temansendiri-pengakuan-saksi-bikin-merinding?page $=4$. 
Tweed, R. G., Bhatt, G., Dooley, S., Spindler, A. Douglas, K. S., \& Viljoen, J. (2011). Youth violence and positive psychology: Research potential through integration. Canadian Psychology, 52, 111-121.

Ungar, M. (2012). The social ecology of resilience a handbook of theory and practice. New York, NY: Springer.

Ungar, M., Brown, M., Liebenberg, L., Cheung, M., \& Levine, K. (2008). Distinguishing differences in pathways to resilience among Canadian youth. Canadian Journal of Community Mental Health, 27, 1-13.

Wilson, M. (2013). Maltreatment and youth delinquency: The relationship between physical neglect and delinquent behavior in young males (Master thesis). Massey University, Manawatu, New Zealand.

Zhang, B., Zhao, F., Ju, C., \& Ma, Y. (2015). Paternal involvement as protective resource of adolescents' resilience: roles of male gender-role stereotype and gender. Journal of Child and Family Studies, 24, 19551965. 